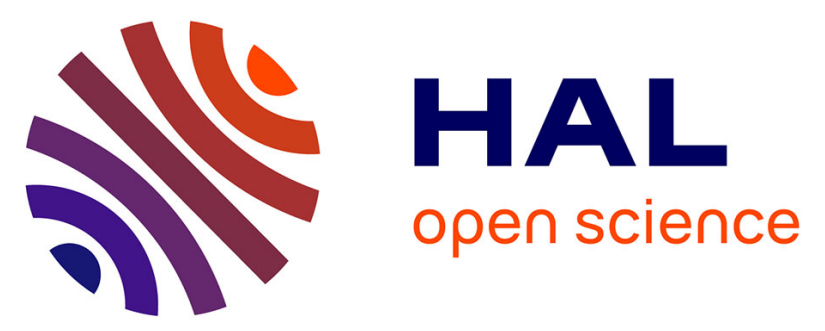

\title{
MIGRESIVES: A RESEARCH PROJECT ON MIGRATION FROM ADHESIVES IN FOOD PACKAGING MATERIALS IN SUPPORT OF EUROPEAN LEGISLATION AND STANDARDISATION
}

Angela Stoermer, Roland Franz

\section{To cite this version:}

Angela Stoermer, Roland Franz. MIGRESIVES: A RESEARCH PROJECT ON MIGRATION FROM ADHESIVES IN FOOD PACKAGING MATERIALS IN SUPPORT OF EUROPEAN LEGISLATION AND STANDARDISATION. Food Additives and Contaminants, 2009, 26 (12), pp.1581-1591. 10.1080/02652030903174831 . hal-00573890

\section{HAL Id: hal-00573890 https://hal.science/hal-00573890}

Submitted on 5 Mar 2011

HAL is a multi-disciplinary open access archive for the deposit and dissemination of scientific research documents, whether they are published or not. The documents may come from teaching and research institutions in France or abroad, or from public or private research centers.
L'archive ouverte pluridisciplinaire HAL, est destinée au dépôt et à la diffusion de documents scientifiques de niveau recherche, publiés ou non, émanant des établissements d'enseignement et de recherche français ou étrangers, des laboratoires publics ou privés. 


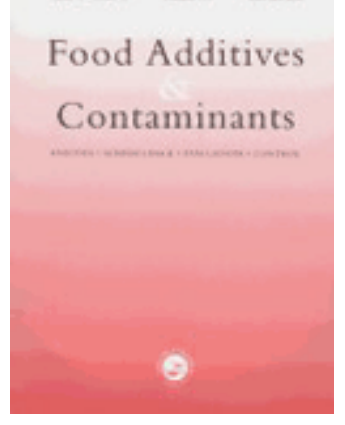

\section{MIGRESIVES: A RESEARCH PROJECT ON MIGRATION FROM ADHESIVES IN FOOD PACKAGING MATERIALS IN SUPPORT OF EUROPEAN LEGISLATION AND STANDARDISATION}

\begin{tabular}{|c|c|}
\hline Journal: & Food Additives and Contaminants \\
\hline Manuscript ID: & TFAC-2008-416.R1 \\
\hline Manuscript Type: & Special Issue \\
\hline $\begin{array}{r}\text { Date Submitted by the } \\
\text { Author: }\end{array}$ & 03-Jun-2009 \\
\hline Complete List of Authors: & $\begin{array}{l}\text { Stoermer, Angela; Fraunhofer Institut Verfahrenstechnik und } \\
\text { Verpackung } \\
\text { Franz, Roland; Fraunhofer Institute, Process Engineering and } \\
\text { Packaging IVV; Fraunhofer Institut Verfahrenstechnik und } \\
\text { Verpackung }\end{array}$ \\
\hline Methods/Techniques: & Chromatographic analysis, Risk assessment - modelling \\
\hline Additives/Contaminants: & Food contact materials, Migration, Packaging - migration modelling \\
\hline Food Types: & \\
\hline
\end{tabular}

\section{SCHOLARONE \\ Manuscripts}


1

2

3

4 Angela Störmer* and Roland Franz,

5 Fraunhofer Institut Verfahrenstechnik und Verpackung, Giggenhauserstr. 35, 85354 Freising,

6 DE

MIGRESIVES: A RESEARCH PROJECT ON MIGRATION FROM ADHESIVES IN FOOD PACKAGING MATERIALS IN SUPPORT OF EUROPEAN LEGISLATION AND STANDARDISATION

8 * Author for correspondence

9 e-mail: angela.stoermer@ivv.fraunhofer.de

\section{Abstract}

Most food packages and food contact materials are manufactured using adhesives. The EU regulates all food contact materials, as their constituents may not contaminate food and endanger consumer's health. In contrast to plastics which are regulated by positive lists of authorised ingredients, adhesives have not yet a specific regulation. The MIGRESIVES project aimed to elaborate a scientific global risk assessment approach to meet current general EU regulatory requirements and as a basis for future specific EU legislation as well as to provide the industry, especially small and medium sized enterprises, a tool to ensure that migration from adhesives is in compliance with the regulatory requirements. The idea was to demonstrate that consumer's exposure to chemicals released by adhesives is in many cases below levels of concern. Technical/scientific knowledge from industry and research institutes will be merged into a collective research endeavour gathering all stakeholders. The major milestones are (i) classification of adhesives according to chemistry and uses, (ii) test strategies based on physico-chemical behaviour of adhesives, (iii) modelling migration/exposure from adhesives, (iv) providing guidelines to integrate the risk assessment approach into the daily life of companies, (v) feasibility of applying the toxicological approach from EU BIOSAFEPAPER project and (vi) extensive training/education to SMEs and large dissemination for general adoption of the concept in Europe.

Key words: Food packaging, adhesives, migration, compliance 


\section{Introduction}

33

34

35

36

37

38

39

40

41

42

43

44

45

46

47

48

49

50

51

52

53

54

55

56

57

58

59

60

61

62

63

64

65

66

67

First of all, it needs to be considered that almost all food packages are manufactured using adhesives. Adhesives are used in flexible film-to-film lamination, paper-film/cardboard-film combinations, rigid multi-layer packaging systems, boxes, sacks, pouches, labels - in most cases without direct food contact but also in some cases with direct food contact. Other special applications are in refrigerators, microwaves, kitchen furniture or corks for alcoholic beverage bottles. In contrast to plastics and paper additives, the term 'adhesives' refers to an extremely large and complex pool of compounds which, by nature, are often subjected to changes in their composition and undergo chemical reactions before the finished packaging materials come to the marketplace (Gierenz and Karmann 2001). Secondly, alarge variety of adhesive systems are used in food packaging materials. The European adhesives industry uses a large range of raw materials with altogether approx. 2000 chemicals (information from FEICA, the Association of European Adhesives Manufacturers) and manufactures adhesive formulations which can comprise up to 15 chemicals, even for the simplest systems. On the other hand, adhesives are used only in a relatively low mass fraction (up to $5 \%$ ) in food contact materials.

The EU regulates generally food contact materials, as their constituents should not be transferred into food in such amounts that may contaminate food and endanger consumer's health. This requirement laid down in Article 3 of Framework Regulation (EC) No. 1935/2004 includes also substances from adhesives. But in contrary to plastics which are specifically regulated by positive lists of authorised monomers and additives, adhesives are not covered by a specific regulation neither on European nor on national levels yet. At the same time, the demands to confirm compliance and ensure packaging safety are increasingly driven both by legislation and food industry. Specifically, a corresponding documentation and the need of accompanying conformity certificates are required by Article 16 of the Framework Regulation (EC) No. 1935/2004, this at each stage of the production chain of a food contact material in Article 9 of the Plastics Directive 2002/72/EG (in the version of the $4^{\text {th }}$ amendment $2007 / 19 / E C)$. This requirement is also addressed in the Regulation (EC) No. 2023/2006 on good manufacturing practice. Today for evaluation of adhesives existing rules and migration testing procedures have to be used which have been established for other materials (e.g. plastics) and which may not satisfy the specific demands of adhesives compliance evaluation. With other words this means where by chance another (EU or national) regulation or recommendation made for plastics, dispersions, elastomers, waxes or paper is applicable for evaluation a certain compound from an adhesives formulation, opportunity will be exploited for this purpose as far as applicable. An important basis for adhesives evaluation is today the US FDA regulation and substance list for adhesives in 21 CFR $§ 175.105$. 
An large body of knowledge on migration from plastic materials has been accumulated in the last 30 years but only a small number of scientific papers have dealt with the potential migration of adhesives constituents (Gruner and Piringer 1999), (Lawson, Barkby et al. 1996; Lawson, Bartram et al. 2000) (Lawson, Barkby et al. 2000), (Davies 2003), (Bradley and Castle 2006).. In addition, more specific studies on migration of primary aromatic amines from polyurethane adhesives in plastics have been carried recently (Brauer and Funke 2002; Brede, Skjevrak et al. 2003; Störmer, Rüter et al. 2005). In 2001, the food control authorities in the Nordic countries organised a seminar to collect and compile knowledge on migration from adhesives (Svensson, Binderup et al. 2001). One important outcome of this seminar was that 'the development of methods of analysis for migrants from adhesives should be prioritized'. The current regulatory 'deficiency' as well as the non-availability of methodological and conceptual compliance test systems in this area was the motivation for us to initiate the MIGRESIVES project within the $6^{\text {th }}$ Framework programme of the European Commission.

\section{The objective of the project}

The EU project MIGRESIVES is funded in the $6^{\text {th }}$ Framework Programme within the Collective Research Programme which supports pre-competitive research for SMEs and their associations. In these kind of projects SMEs are typically represented by their associations and a core group of actively involved SMEs. Beneath some large multinational global players, in the European adhesive industry there is a large number of small and medium sized enterprises (SMEs). The adhesive sector in Europe comprises more than 500 SMEs spread throughout the continent with a majority in Germany, France, Italy and Great Britain. Most of these companies are affiliated to the Association of European Adhesives Manufacturers, FEICA, via 15 national member associations.

Approaches to compliance testing and evaluation should consider these SME type industrial structure and the corresponding characteristics and needs: these are the large diversity of substances and at the same the small market share of adhesives in terms of relatively small production batches. With other words, approaches to be taken should be cost-efficient, pragmatic and nevertheless not compromise consumer safety.

For specific regulation of adhesives in principle two potential regulatory approaches can be envisaged ::

Approach 1 would be a positive list system for authorized chemicals in adhesive raw materials in analogy to the current EU system for plastic food contact materials. This means that every raw material and additive needs to be approved by EFSA and the Commission 
102 regardless whether they are expected to migrate into food or not. All other (unlisted)

103 compounds would then need to be excluded from use. Building up such a positive list would

104 be extremely time-consuming and would be an enormous cost burden on the adhesive

105 industry due to the multitude of individual substances and because only a small fraction of

106 the raw material substances are already evaluated by EFSA. Full toxicological evaluation

107 and authorisation of all other substances would not only over-challenge the economics of the

108 European SME industry but also the capacities of the EFSA. Furthermore, the functionality

109 and processing of adhesives systems are by nature largely based on chemical reactions and

110 hence the reaction products and by-products would also have to be measured and

111 evaluated, meaning that even more toxicological data and knowledge would be necessary.

112 From this it appears that the positive list approach may have more drawbacks than

113 advantages and would in any case not be practicable. In this context it should be stressed

114 that the exposure of consumers to contaminants released by adhesives is much smaller than

115 by materials in direct food contact applications. This smaller exposure would justify a

116 different approach to safety assessment.

117 Approach 2, an alternative would be to consider the actual migrating substances and their

118 exposure to the consumer, but not the full list of potential migrants (as per Approach 1). This

119 different approach can be seen in analogy to the functional barrier principle for plastic multi-

120 layers as introduced into the Plastics Directive 2002/72/EC by its $4^{\text {th }}$ amendment

121 2007/19/EC. According to its Article 7a, substances which are not in the positive list, may be

122 used in non-food contact layers of a multilayer material if they do not migrate into the food in

123 amounts exceeding $0.01 \mathrm{mg} / \mathrm{kg}$ food and if they are not classified as proved or suspect

124 "carcinogenic", "mutagenic" or "toxic to reproduction", officially as well as under self-

125 responsibility criteria. Adhesives are in most cases not in direct contact with the foods and

126 are usually separated from the foods by a plastic, paper or cardboard layer. Furthermore,

127 adhesives which make up only a very small fraction of the total mass of food contact

128 materials, are likely to cause only a relative low consumer exposure. The classification of the

129 substances in migration relevant ones and those which are not expected to be transferred

130 into foods, can be achieved by consideration of the practical applications of adhesives and

131 the parameters influencing the migration of adhesive constituents into foods.

132 The aim of the MIGRESIVES project was to provide the scientific basis and the necessary

133 tools to step into approach 2. In the underlying Collective Research Programme of the $6^{\text {th }}$

134 Framework Programme the specific needs of SMEs should be considered and corresponding

135 solutions be provided. The MIGRESIVES project addresses therefore the following

136 objectives: 
137 - To develop a pragmatic, science based concept and methodological tools to ensure 138 consumer safety related to adhesives used in food contact materials. This concept should 139 find European recognition and could be an option for being integrated into a more specific 140 European legislation on adhesives

141 - To train industry (especially SMEs) using the tools of the developed concept and to 142 rationalise and disseminate the project outcome as rules and guidelines to the whole food 143 packaging chain.

144 - To support and strengthen SME competitiveness within the adhesives industry and the 145 added value chain by ensuring product safety through cost-efficient application of the 146 concept and its tools. In this way existing markets should be saved and opening of new 147 markets enabled.

\section{Structure of the project}

150 The project started in February 2007 with a duration of 3 years. It has funding of 3.09 Mio 151 Euro and an EU contribution of 1.94 Mio Euro. The project consortium consists of 21 152 partners (table 1) with 7 associations, 7 SMEs and 7 research institutes from 6 European 153 countries. The associations represent the SME adhesives industry with the European association FEICA and the national ones in Germany, France and Spain. Furthermore, plastics converter and the producer of paper \& board packaging as well as cork stopper producers are represented by one association each. The SME core group consists of five adhesive producer and two retailers of cork stoppers. Altogether, the producers as well as the user of adhesives for food contact applications are involved in the project.

The project work is structured into 8 work packages (figure 1) which will be described below.

\section{The concept frame}

The basic idea is to elaborate a testing concept and tools in connection with a suitable classification of adhesives components and applications in FCM according to their migration potential. The tools will comprise of theoretical evaluations, analytical methods and mathematical migration modelling.

Adhesives components may be classified into the following five groups:

- Substances which do not migrate.

- Substances which do not migrate at a given functional barrier (application, contact conditions). 
169

170

171

172

173

174

175

176

177

178

179

180

181

182

183

184

185

186

187

188

189

190

191

192

193

194

195

196

197

198

199

200

201

- Substances which are evaluated in an EU-list and have a specific migration limit which cannot be exceeded at the intended application.

- Substances which are evaluated in an EU-list and have a specific migration limit which need to be measured.

- Not yet evaluated substances, which can migrate in such amounts that a toxicological evaluation would be necessary.

\section{Classification of adhesives, definition and preparation of test systems}

A classification of adhesives can typically be made on the basis of chemical composition, setting mechanism, adhesion mechanism and form of application, application temperature and end-uses (Gierenz 2002). A classification according to the setting mechanism is compiled in Ullmans Enzyclopedia (Gierenz 2002; Gruber and Rich 2002) and by (Onusseit 2008). A flexible classification in which each adhesive is characterised and classified according to various features such as chemical basis, form of application, application temperature, thermal behaviour and uses as proposed by Lucke ((Lucke 1967), cited in (Gierenz 2002)) is judged by Gierenz as highly comprehensive (Gierenz 2002). For evaluation of migration, considering a broad range of features from chemistry and composition to applications is necessary as well. The literature as mentioned above relates to all technical applications, none especially to applications for food contact materials. On the basis of common adhesives categories a specific classification is made in the project with respect to the intention of the project which means by considering also the potential of adhesive constituents migration into food. Such a classification is a complex issue and not available today. It requires an intensive discussion using the know-how and expertise of the project consortium.

The classification of the adhesives, adhesive compounds, applications and their migration potential should support the following objectives:

- Structuring adhesive compounds, adhesive types, applications as a tool for selection representative test systems (operational objective for the project)

- Collecting information on substance properties, regulations, existing toxicological evaluations, migration potential and on applications needed for

- Experimental determination

- Mathematical modelling

- Choice of a suitable pathway to obtain the migration value by estimation or experimentation. 
203 For selection of representative test systems it was agreed within the consortium that it would 204 be the best approach to classify according to the raw material polymer type, the reactivity 205 and the solvent system. Adhesives where the polymer is made from pre-polymers or 206 monomers during curing are compiled as reactive ones and those which cure physically (e. 207 g. by drying or temperature application) as non-reactive. The solution type is divided in three 208 classes. $100 \%$ systems compile all solvent free systems (solvent free reactive systems as 209 well as non-reactive hotmelt systems). The other two classes are the water based and the 210 (organic) solvent based systems (Figure 2).

211 Starting from this classification, the relevant adhesive types for food contact material 212 applications and their applications have been collected. The scheme (Table 2) was 213 established within the consortium. This classification reflects the chemistry of the adhesives 214 as well as the complexity arising from numerous parameters in the end use of the system 215 (Substrates, packaging design, means/type of application, etc.). In this scheme the adhesive 216 systems which are included as test samples in the project are marked. Finally the experience 217 of the affected industry, adhesive industry as well as packaging converters of paper \& board 218 and plastics was included to obtain an as complete as possible overview on food packaging 219 related adhesive systems and applications and a representative selection of adhesive 220 systems for the research work.

221 Based on the classifications made above, 23 representative test systems had been defined 222 and selected by the consortium with the intention to be typical for adhesives formulations, 223 materials and structures used for food contact materials and to include different application 224 and handling conditions: like type of food, type of contact, temperature and storage 225 conditions. Furthermore a range of cork stopper applications with polyurethane adhesives 226 are investigated in the project. All these test systems are used for the comprehensive studies 227 within WP 2. Additionally to the project consortium, the selection of test samples has been 228 discussed within the converter associations, partner IK and MCAS, and their input has been considered in order to ensure representativeness.

\section{Method development for screening multi-methods and quantitative approach to} 231 groups and unknowns

232 The objectives are the development of screening methods covering most chemical classes of 233 adhesive relevant substances up to a molecular weight of $1000 \mathrm{~g} / \mathrm{mol}$ and the development 234 and validation of methods for semi-quantification of unknown substances by universal standard substances. 
236 The substances in adhesives derive from various chemical classes (functional groups) and 237 cover the whole range of physico-chemical properties from volatile to non-volatile, from polar 238 to non-polar. For investigation of these substances up to a molecular weight of $1000 \mathrm{~g} / \mathrm{mol}$, 239 the development of methods is necessary which cover broad ranges of physico-chemical 240 properties so that many compounds can be analysed simultaneously in one analytical run. 241 For this in a first step methods are developed using standards and standard mixtures of 242 known adhesive related substances. A list of more than 50 substances was established: 243 monomers, additives, some solvents. The substances have different physico-chemical 244 properties and are available as pure standards. The techniques which have been used were 245 gas chromatography for the volatile and semi-volatile compounds, HPLC for the non-volatile 246 ones. An aim was to minimise the number of techniques or chromatographic conditions 247 necessary for obtaining the compositional information generally or in dependency of the 248 adhesives class. The applicability and the boundaries of the existing and the new developed 249 multi-methods were checked for the adhesive relevant substances and whole groups of 250 substances.

251 Furthermore, WP2b endeavours to develop a quantitative approach to substance groups or 252 unknowns. This approach, however, must implicate sufficient safety margins. This represents 253 a scientifically challenging task within the project which would be of high importance not only 254 for the adhesives compliance testing area but also for other migration potentials from other 255 material categories. The approach to quantify unknown volatile to semi-volatile substances 256 by universal internal standard substances with GC-FID is already used in various labs. The 257 FID signal correlates to the mass of carbon atoms per time unit and therefore the signal 258 should be more or less independent from the chemical structure and the derived 259 concentration $(\mathrm{w} / \mathrm{v})$ should only depend on the ratio of carbon to non-carbon atoms related to 260 that in the internal standard. Howewer in reality further parameters like peak shape as well 261 as the molecular structure and the functional groups influence the response factor.

262 Comparative investigations had been mainly performed on alkanes and polyaromatic 263 hydrocarbons (e.g. (Tong and Karasek 1984; Blanco, Canga et al. 1992; Slemr, Slemr et al. 264 2004)). Systematic work to predict the FID response from molecular structure was done e.g. 265 by Jorgensen et al. (Jorgensen, Picel et al. 1990)and Kállai and Balla (Kállai and Balla 2002). 266 The reactions within the FID are not yet completely understood so that empirical data 267 especially for complex structures are necessary. First results on the comparison of relative 268 response factors using tert-butyl-hydroxy-anisole (BHA) as internal standard look highly 269 promising (Gruner, Yoon et al. 2008) and shall be published separately.

270 For the determination of non-volatile groups and unknowns using HPLC the situation is more 271 difficult. The applicability of an universal standard approach to the non-volatile adhesive 

1

272 related substances was tested. This however needed a HPLC detection system which is, in 273 analogy to the GC-FID system, dependent on the mass only. Modern possibilities for that are 274 in principle evaporative light scattering detectors (ELSD) or charged aerosol detection (CAD). 275 Both detectors may work for this purpose because of their working principles. The CAD 276 showed better sensitivity and was used for the study. First results are shown (Yoon, 277 Ungewiss et al. 2008) and will be published separately.

278 Furthermore, for increasing sensitivity of determining volatiles a screening method base on 279 solid phase microextraction coupled with gas chromatography was developed by Nerin et al. 280 [to be referenced later: publication of Nerin et al in this issue on the ILSI conference].

\section{Compositional analyses and studies}

282 Any migration behaviour concept must include as a starting point the possible concentrations 283 of potential migrants and their identities in the material itself. This is essential for any 284 migration prediction. For non-reactive adhesives this concerns all the constituents in the raw 285 materials and in the adhesives formulations and their end concentrations in the final food 286 contact material applications. For reactive adhesives, where during processing or even 287 storage in contact with food reaction products can be formed, or in case of thermal 288 decomposition from non-reactive systems further chemical compounds are of interest and 289 need to be considered.

290 The pure adhesives, the glued test systems as well as the reference substrates are extracted 291 and submitted to a screening analysis using the multi-methods. The substances which are 292 for migration studies were defined from these results. They need to be present in sufficiently 293 high concentrations in the test system in order to obtain measurable values in the migration 294 experiment. The initial concentrations of these substances are quantified. Furthermore 295 additional peaks are characterised and as far as possible identified by coupling GC or HPLC 296 with mass spectrometry. In addition, comprehensively, by a theoretical approach 297 characteristic constituents of adhesives are checked on the possibility of forming reaction or 298 degradation products from chemistry considerations.

\section{Migration \& partitioning studies}

300 WP2c generates essential physico-chemical data such as diffusion coefficients and partition 301 coefficients which control the mass transport phenomena in the test systems and which are used for establishing rapid and predictive migration test tools in WP3. For mathematical 303 modelling of migration, knowledge on diffusion coefficients in the adhesives and the 304 substrate layers as well as partitioning coefficients of the adhesive related substances 305 between adhesive and substrate layers as well as between substrate and food simulant is 
306 necessary. Estimation of diffusion coefficients in plastic layers is state of the art but data for 307 estimating diffusion in adhesive layers and in paper and board are missing. Knowledge on 308 partitioning coefficients is lacking, too.

309 For mass transport studies to be carried out in this WP there are no standard tests available 310 especially for thin layers and for migration from paper and board where the classical 311 simulants are not applicable. The liquid simulants will in many cases extract these packaging 312 systems and may, therefore, lead to unrealistic high migration compared to foods which 313 would not penetrate into these packaging systems. Therefore, especially simulants or, better 314 to say, acceptor media for the migrating substances are applied which do not interact with 315 the substrate. These are solid simulants e. g. the official simulant Tenax® (modified 316 polyphenylene oxide), plastic films (LDPE) or paper and board. For testing plastic multilayers 317 without interaction with the material, Brandsch and Piringer had successfully used LDPE-film 318 as acceptor simulant (Brandsch, Gruner et al. 2005). For some relatively polar migrants as 319 they are used in water based adhesives, LDPE showed too weak acceptor properties. 320 Investigating the partitioning between adhesive and substrate as well as the diffusion in the 321 adhesive and the substrate by using the virgin substrate (paper or paperboard) itself as 322 acceptor medium turned out to be a good alternative. The diffusion in plastic layers or 323 paper\&board as acceptor media can be better modelled than in the Tenax® granules and is 324 therefore preferred from a modelling sight for deriving the experimental data for partitioning 325 and diffusion in adhesives and substrates. Tenax $\AA$ experiments are carried out additionally 326 to simulate the food contact especially for dry foods.

327 Two principal approaches for migration testing are performed: Kinetic test where migration is 328 resolved by time and migration into a stack of acceptor layers where migration is resolved by 329 distance from the contact surface. In the kinetic approach a thick LDPE layer $(500 \mu \mathrm{m})$ or a 330 cardboard is pressed on both sides of a test system (e. g. cardboard/adhesive/cardboard) in 331 a stainless steel cell or Tenax is applied on one surface in a glass cell. The concentration in 332 the acceptor layers is determined and correlated to the contact time. In the second approach 333 migration is resolved by distance from the contact surface (Moisan 1980). For this, a stack of 334 ten to twenty thin LDPE films or paper sheets is pressed onto the test system in the same 335 steel cell for a defined time. After contact the concentration of the target migrant is 336 determined in each layer of the stack and correlated to the distance from the test system 337 surface. In order to obtain the temperature dependencies of the partitioning and diffusion 338 coefficients, the migration experiments are carried out at different temperatures (e. g. $20{ }^{\circ} \mathrm{C}$, $33940^{\circ} \mathrm{C}, 60^{\circ} \mathrm{C}$ ). The experimental data are used for calculation diffusion and partitioning 340 coefficients by the multilayer migration model in WP 3. 
As additional approaches diffusion coefficients of fluorescent dyes doted into adhesives are determined by Fluorescence Recovery After Photobleaching (FRAP) (Pinte, Joly et al. 2008) and partitioning coefficients between adhesives and substrates of supplementary additives mixed to those present in the test systems are measured in order to investigate into correlations between partitioning coefficients and polarity parameters.

\section{Quick tests, mathematical modelling and predictive tools}

Today, in compliance testing of food contact materials, it is common to apply conventional migration test procedures with standardised test conditions. These procedures do have the big disadvantage that they are very time and work consuming and therefore costly. On the other hand, based on scientific progress in the area, alternative compliance assessment approaches have been proposed and are increasingly used but still with too much hesitation. The aim of this work package is to establish with the WP2 results such alternative compliance assessment procedures for food contact materials based on adhesive technology. These procedures are combinations of experimental quick-tests and theoretical techniques with predictive character which, by definition, need to be more severe than conventional tests. The elements of these alternative procedures are called 'tools' in the following.

The numerical mathematical tools to model migration from multilayer materials (Piringer and Baner 2008) and software solutions to use it are already available (AKTS 2007; INRA 2007; FABES 2008). But the diffusion and partitioning parameters to be introduced into the model need to be established. For this the diffusion and the partitioning coefficients are fitted in the model to the experimental data derived from WP 2 . This work is done by project partner FABES. Comparison of the derived parameter at different temperatures enables to extrapolate the modelling parameters to other contact conditions (time, temperature). Furthermore when having a sufficient amount of various data from different substances, extrapolation of modelling parameters to other substances will become possible. By linking the model with the results of the FOODMIGROSURE project, migration can be modelled into real foods (FOODMIGROSURE 2008).

It should be noted that modelling is only one of the tools in the concept. All information, experimental results and experiences with the test samples will be compiled to work out procedures starting from the knowledge on the adhesive composition and application in the finished food contact material via analytical tests and mathematical modelling resulting in a regulatory evaluation. For this, decision trees shall be established that structure the compliance concept. In some cases theoretical considerations might be sufficient to come to a compliance evaluation, in others analytical measurements will be necessary. Test 
376 conditions for analytical quick tests (accelerated migration tests) shall be defined in order to 377 obtain results for rapid evaluation of migration.

\section{Screening of samples from the market}

379 The applicability of the analytical quick tests and of the migration prediction tools which are 380 developed in WP 2 and WP 3 to other adhesives formulations and food packaging 381 applications are investigated in order to generalise the tools. Whereas in WP 2 all samples 382 have been fully area laminated with adhesives, in WP 4 packages with real adhesive 383 applications (e. g. lines, dots) are investigated. The tools from WP 2 and 3 are to be tested 384 on some of the adhesives in WP 2 in finished packages but mainly on additional formulations 385 and adhesives of further manufacturers. Also additional end-uses are considered, e. $g$. 386 sterilisation, vacuum packaging or heating in microwave or oven. The aim is to verify the 387 tools and to broaden the applicability. The materials are investigated according to the 388 decision tree developed in WP3. This includes in any case a compositional analysis using 389 the tools from WP 2. Quick tests and mathematical migration prediction (from WP3) will be 390 applied and compared to conventional migration tests in food simulants.

\section{Global in vitro bioassays - a feasibility study}

392 The EU project 'Biosafepaper' (QLK1-CT-2001-00930, project duration 1.12.2001-

393 30.11.2005) has been developing bioassays for paper \& board as alternative approach for 394 safety assessment of these materials compared to investigation of single substances. In that 395 project a test battery of different in-vitro toxicological tests with different endpoints was 396 selected as basis for a decision tree approach in safety evaluation, appropriate extraction 397 methods for paper \& board have been elaborated (Bradley, Honkalampi-Hämäläinen et al. 398 2008). The big advantage of such an approach would be in principle, not necessarily to 399 investigate and to evaluate each single substance which migrates but to have global 400 toxicological endpoints for evaluation of the total of migrating substances. Within the 401 MIGRESIVES project the chance shall be taken to check the feasibility for additional 402 applications related to adhesives using the tools elaborated for paper \& board. Like paper \& 403 board, adhesives contain a large number of different migratable substances which makes 404 this global approach in principle very interesting. The workpackage is designed as a small 405 and limited feasibility study and will not investigate in further validation of such a bioassay 406 approach. Ethanolic extracts of the pure adhesives, the laminates and the pure substrates 407 are subjected to a RNA synthesis inhibition test as cytotoxicity/sublethyl toxicity assay 408 (Valentin-Severin, Laignelet et al. 2002; Jondeau, Dahbi et al. 2006; CEN 2008), to AMES 409 test employing Salmonella typhimurium strains TA98, TA100, TA1535 and 1537 along with 410 Escherichia coli strain WP2 uvrA (pKM101) both in the presence and absence of an 


\section{1}

411 exogenous metabolic activation system (OECD 1997) and to the Comet assay (Collins,

412 Oscoz et al. 2008).

\section{Education \& training}

414 Since the project is dedicated to small and medium sized enterprises they should be the first 415 who should be able to use the concept of MIGRESIVES for their compliance evaluations. To 416 realise this, the SMEs need to be trained to be able to apply the concept for their own 417 products; this either alone or in cooperation with testing laboratories. Furthermore it is the 418 intention of the project to reach more SMEs than those which will be able to attend a 419 workshop within the project and to spread the concept to further countries which are not 420 represented in the consortium by their associations. In order to achieve this, multipliers from 421 different countries will be trained additionally so that they should be able to explain the 422 423 concept to the associations and the SMEs in their countries. Detailed lessons with presentations and additional explanations will be provided in English language and translated within the project into German, Spanish and French. It is planned to make the lessons available in further languages in cooperation with the trained multipliers and the national associations after the end of the project. The training will consist of three modules: (1) Current legislation of food contact materials in the EU, (2) the MIGRESIVE concept and tools, (3) Use of the modelling software. At a later stage (after the project) the whole food packaging chain, i. e. the adhesive users, the packaging converters up to the food industry as well as the raw materials producers should have access to the project tools.

\section{Standard test methods, guidelines and link to the stakeholders}

The project results are intended to support legislation and standardisation. Analytical 434 methods will be provided in standard format and the whole concept will be laid down in form of a guideline. They may be proposed to the European Standardisation Body CEN.

In order to enhance the awareness and recognition of the project and the approach at all parties concerned and to promote the European consensus, various activities are and will be undertaken on national and European level e. g. presentations at public conferences and workshops as well as at association meetings. Not only adhesives industry but the whole production chain from raw material producer to food packer is addressed. Furthermore the European Food Safety Authority EFSA as well as the European Commission (DG Sanco) will be kept informed and, at a later stage of the project when more results are available, invited to discuss the concept. At the end of the project, a closing conference is planned to give the possibility for a broad discussion by all stakeholders. These dissemination actions are subsumed in WP 8. 


\section{Conclusions and perspectives}

446 The complexity of adhesive systems and applications in connection with various substrates

447 makes the work highly challenging. Furthermore, only very limited publicly available

448 information is available on adhesive composition and used of additives as well as no 449 statistical data for food contact application uses. The representativeness of the adhesive 450 systems chosen for the project is therefore based on a broad involvement of industries 451 experience both from adhesive side and from packaging converter side. So it is ensured that 452 the test systems in the project cover the most important adhesive types for food contact 453 materials. An extensive experimental workload is necessary to establish the scientific basis 454 for the project tools and the overall concept.

455 Conventional migration tests give results in simulants which can be very different from 456 migration with real food applications (O'Neill, Tuohy et al. 1994; Castle, Honeybone et al. 457 2000; EFSA 2005; Franz 2005; Störmer and Franz 2008). From our perspective, the project 458 outcome may be successfully connected with the results from the recent 459 FOODMIGROSURE project (FOODMIGROSURE 2008) and with the recently started FACET 460 (FACET 2008). This will allow into-food migration modelling and, in the future, also exposure 461 estimation from adhesives used in FCM.

\section{Acknowledgement}

463 Work was and is supported by the European Union under the Collective Research 464 Programme Contract No. COLL-CT2006-030309 MIGRESIVES. The findings and 465 conclusions in this paper are the responsibility of the authors alone and should not be taken 466 to represent the opinion of the European Commission. The authors gratefully appreciate 467 pleasant cooperation with all project partners.

\section{References}

AKTS (2007). Software AKTS-SML, AKTS AG, 3960 Siders, Switzerland.

Blanco, C. G., J. S. Canga, et al. (1992). "Flame ionization detection relative response factors of some polycyclic aromatic compounds. Determination of the main components of the coal tar pitch volatile fraction." Journal of Chromatography 607: 295-302.

Bradley, E. L. and L. Castle (2006). Chemical migration from adhesives used in food contact materials and articles. FSA Project A03044, Food Standards Agency, London. Bradley, E. L., U. Honkalampi-Hämäläinen, et al. (2008). "The BIOSAFEPAPER project for in vitro toxicity assessments: Preparation, detailed chemical characterisation and testing of extracts from paper and board samples." Food and Chemical Toxicology 46(7): 2498-2509.

Brandsch, R., A. Gruner, et al. (2005). "Migrationsuntersuchungen zur Prüfung und Bewertung von Stoffübergängen aus flexiblen Mehrschichtkunststoffen in Lebensmittel." Deutsche Lebensmittel-Rundschau 101: 549-559. 
483 Brauer, B. and T. Funke (2002). "Spezifische Bestimmung primärer aromatischer Amine in

484

485

486

487

488

489

490

491

492

493

494

495

496

497

498

499

500

501

502

503

504

505

506

507

508

509

510

511

512

513

514

515

516

517

518

519

520

521

522

523

524

525

526

527

528

529

530

531

532

533

534

535

536

537

538 wässrigen Migraten von Bedarfsgegenständen aus Kunststoff = Specific determination of primary aromatic amines in aqueous migration solutions from food contact articles." Deutsche Lebensmittel-Rundschau 98(11): 405-411.

Brede, C., I. Skjevrak, et al. (2003). "Determination of primary aromatic amines in water food simulant using solid-phase analytical derivatization followed by gas chromatography coupled with mass spectrometry." Journal of Chromatography A 983(1-2): 35-42.

Castle, L., C. A. Honeybone, et al. (2000). Establishment of a Migration Test Method for Fatty Contact. BCR Information Chemical Analysis. EU Report 19376 EN.

CEN (2008). prEN 15845. Paper and board - Determination of the cytotoxicity of aqueous extracts.

Collins, A. R., A. A. Oscoz, et al. (2008). "The comet assay: topical issues." Mutagenesis 23(3): 143-151.

Davies, J. S. (2003). Migration of Adhesives in Food Packaging. Department of Chemistry. Leichester LE1 9BH, UK, De Montfort University. PhD thesis: $170 \mathrm{p}$.

EFSA (2005). "Opinion of the Scientific Panel on food additives, flavourings, processing aids and materials in contact with food (AFC) related to 2-Isopropyl thioxanthone (ITX) and 2-ethylhexyl-4-dimethylaminobenzoate (EHDAB) in food contact materials " The EFSA Journal 293: 1-15.

FABES (2008). Software MIGRATESTCEXP, FABES ForschungsGmbH, München.

FOODMIGROSURE (2008). Modelling migration from plastics into foodstuffs as a novel and cost efficient tool for estimation of consumer exposure from food contact materials Final synthetic report EU project QLK1-CT2002-2390. www.foodmigrosure.com.

Franz, R. (2005). "Migration modelling from food-contact plastics into foodstuffs as a new tool for consumer exposure estimation." Food Additives \& Contaminants: Part A 22(10): 920-937.

Gierenz, G. (2002). Adhesives - 5. Classification of Adhesives. Ullmann's Encyclopedia of Industrial Chemistry. Weinheim, Wiley- $\mathrm{VCH}$. electronic Version.

Gierenz, G. and W. Karmann (2001). Adhesion and Adhesive Tapes. Brisbane; Chichester; New York; Weinheim, Wiley-VCH.

Gruber, W. and R. D. Rich (2002). Adhesives - 6. Individual Adhesive Systems. Ullmann's Encyclopedia of Industrial Chemistry. Weinheim, Wiley-VCH. electronic Version.

Gruner, A. and O. G. Piringer (1999). "Component migration from adhesives used in paper and paperboard packaging for foodstuffs " Packaging Technology and Science 12(1): 19-28.

Gruner, A., C. S. Yoon, et al. (2008). Semi-quantitative determination of potential migrants in food packaging materials - Part 2: Semi-volatile compounds. Poster at ILSI 4th International Symposium on Food Packaging - Scientific Developments supporting Safety and Quality. Prague, 19.-21. November 2008.

INRA (2007). SAFE FOOD PACKAGING PORTAL, http://h29.univ-reims.fr/.

Jondeau, A., L. Dahbi, et al. (2006). "Evaluation of the sensitivity of three sublethal cytotoxicity assays in human HepG2 cell line using water contaminants." Toxicology 226(2-3): 218-228.

Jorgensen, A. D., K. C. Picel, et al. (1990). "Prediction of gas chromatography flame ionization detector response factors from molecular structures." Analytical Chemistry 62(7): 683-689.

Kállai, M. and J. Balla (2002). "The effect of molecular structure upon the response of the flame ionization detector." Chromatographia 56(5): 357-360.

Lawson, G., C. T. Barkby, et al. (2000). Chemical Composition and Migration Levels of Packaging Adhesives. MAFF Project FS 2223.

Lawson, G., C. T. Barkby, et al. (1996). "Contaminant migration from food packaging laminates used for heat and eat meals." Fresenius' Journal of Analytical Chemistry 354(4): 483-489.

Lawson, G., S. Bartram, et al. (2000). "MALDI-MS and colorimetric analysis of diisocyanate and polyol migrants from model polyurethane adhesives used in food packaging." Analyst 125: 115 - 118. 
539 Lucke, H. (1967). Kunststoffe und ihre Verklebung. Hamburg, Verlag Brunke Garrels.

Moisan, J. Y. (1980). "Diffusion des additifs du polyethylene--I: Influence de la nature du diffusant." European Polymer Journal 16(10): 979-987.

Headings of figures and tables

Figure 1: Overview of project work packages

O'Neill, E. T., J. J. Tuohy, et al. (1994). "Comparison of milk and ethanol/water mixtures with respect to monostyrene migration from a polystyrene packaging material." International Dairy Journal 4(3): 271-283.

OECD (1997). "OECD Guideline for testing of chemicals 471. Bacterial reverse mutation test $"$.

Onusseit, H. (2008). Praxiswissen Klebtechnik - Band 1 Grundlagen. Heidelberg, München, Landsberg, Berlin, Hüthig.

Pinte, J., C. Joly, et al. (2008). "Proposal of a Set of Model Polymer Additives Designed for Confocal FRAP Diffusion Experiments." Journal of Agricultural and Food Chemistry 56(21): 10003-10011.

Piringer, O. G. and A. L. Baner, Eds. (2008). Plastic Packaging: Interactions with Food and Pharmaceuticals

Weinheim Wiley-VCH.

Slemr, J., F. Slemr, et al. (2004). "Study of the relative response factors of various gas chromatograph-flame ionisation detector systems for measurement of C2-C9 hydrocarbons in air." Journal of Chromatography A 1061(1): 75-84.

Störmer, A. and R. Franz (2008). Migration of plastic constituents. Plastic Packaging: Interactions with Food and Pharmaceuticals. O. G. Piringer and A. L. Baner. Weinheim Wiley-VCH: 349-416.

Störmer, A., M. Rüter, et al. (2005). Früherkennung und Sicherung der Konformität isocyanathaltiger, funktioneller Schichten. Abschlussbericht BMBF-Projekt Nr. 033 0347, Deutsches Bundesministerium für Bildung und Forschung.

Svensson, K., M.-L. Binderup, et al. (2001). Adhesives in food contact materials and articles proceedings from a Nordic seminar June 2001. Adhesives in food contact materials and articles - proceedings from a Nordic seminar June 2001.

Tong, H. Y. and F. W. Karasek (1984). "Flame ionization detector response factors for compound classes in quantitative analysis of complex organic mixtures." Analytical Chemistry 56(12): 2124-2128.

Valentin-Severin, I., L. Laignelet, et al. (2002). "Uridine uptake inhibition assay: an automated micromethod for the screening of cytotoxicity." Toxicology 171(2-3): 207-213.

Yoon, C. S., J. Ungewiss, et al. (2008). Semi-quantitative determination of potential migrants in food packaging materials - Part 3: Non-volatile compounds. Poster at ILSI 4th International Symposium on Food Packaging - Scientific Developments supporting Safety and Quality. Prague, 19.-21. November 2008.

Table 1: Overview project consortium

Table 2: Classification of adhesives for FCM according to base polymer, solvent system and 586 curing type as well as typical applications.

Figure 2: Classification of adhesives according to raw material polymer, reactivity and solvent system 


\section{Figure 1}

WP 1 Classification of adhesives, definition \& preparation of test systems

WP 2 Analytical \& physico-chemical experimental core studies

- WP 2a: Compositional analyses and studies

- WP 2b: Quantitative approach to groups \& unknown substances

- WP 2c: Migration \& partitioning studies

\begin{tabular}{|c|c|c|}
\hline $\begin{array}{l}\text { WP } 3 \text { Development } \\
\text { of quick tests, } \\
\text { migration model and } \\
\text { predictive tools }\end{array}$ & $\begin{array}{l}\text { WP } 4 \text { Screening of samples from } \\
\text { the market for broader } \\
\text { applicability of testing tools and } \\
\text { verification purposes }\end{array}$ & $\begin{array}{l}\text { WP } 5 \text { Global in-vitro } \\
\text { bioassays derived } \\
\text { from paper\&board } \\
\text { studies }\end{array}$ \\
\hline $\begin{array}{l}\text { WP } 6 \text { Education \& } \\
\text { training to adopt the } \\
\text { concept at SME } \\
\text { industry }\end{array}$ & $\begin{array}{l}\text { WP } 7 \text { Drafting standard test } \\
\text { methods and guidelines how to } \\
\text { use predictive tools and apply the } \\
\text { concept }\end{array}$ & $\begin{array}{l}\text { WP } 8 \text { Linking the } \\
\text { project with } \\
\text { stakeholders }\end{array}$ \\
\hline
\end{tabular}




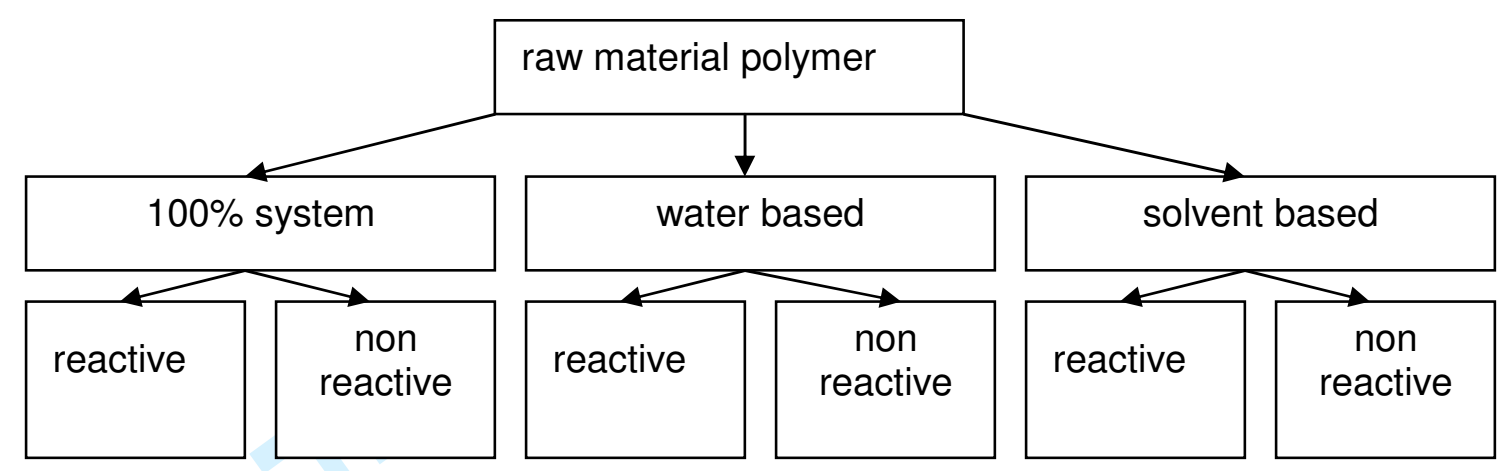

Figure 2 


\begin{tabular}{|c|c|c|}
\hline Type & Partner & Country \\
\hline RTD & Fraunhofer Institut für Verfahrenstechnik und Verpackung IVV & $\mathrm{DE}$ \\
\hline IAG & FEICA - Association of European Adhesives Manufactures e.V. & BE \\
\hline IAG & Industrieverband Klebstoffe e.V., IVK & DE \\
\hline IAG & $\begin{array}{l}\text { Asociación Espanola de Fabricantes de Colas y Adhesivos, } \\
\text { ASEFCA }\end{array}$ & ESP \\
\hline IAG & $\begin{array}{l}\text { Association Club "Materiaux pour Contact Alimentaire et Santé" } \\
\text { filiere papier/carton, Club MCAS }\end{array}$ & FRA \\
\hline IAG & IK Industrievereinigung Kunststoffverpackungen & DE \\
\hline IAG & $\begin{array}{l}\text { Groupement pour la codification des mesures des bouchons de } \\
\text { liège, Codiliège }\end{array}$ & FRA \\
\hline IAG & $\begin{array}{l}\text { Association Française des Industries de Colles, Adhesifs et Mastics, } \\
\text { ASEFCA }\end{array}$ & FRA \\
\hline RTD & Institut National de la Recherche Agronomique, INRA & FRA \\
\hline RTD & $\begin{array}{l}\text { FABES Forschungs-GmbH für Analytik und Bewertung von } \\
\text { Stoffübergängen }\end{array}$ & DE \\
\hline RTD & $\begin{array}{l}\text { Universidad de Zaragoza, Instituto de Investigaciôn en Ingenieria } \\
\text { de Aragôn (I } 3 A \text { ) - }\end{array}$ & ESP \\
\hline RTD & $\begin{array}{l}\text { Centre technique de la Conservation des Produits Agricoles, } \\
\text { CTCPA }\end{array}$ & FRA \\
\hline RTD & Institut Textile et Chimique de Lyon, ITECH & FRA \\
\hline RTD & $\begin{array}{l}\text { Université de Bourgogne-ENSBANA "ERT Sécurité alimentaire- } \\
\text { Emballages" }\end{array}$ & FRA \\
\hline SME & Eukalin Spezial Klebstoff Fabrik GmbH & DE \\
\hline SME & Gludan A/S. & DK \\
\hline SME & Türmerleim $\mathrm{GmbH}$ & DE \\
\hline SME & Samtack S.L. & ESP \\
\hline SME & 8 & SLO \\
\hline SME & Belbo Sugheri & ITA \\
\hline SME & Pietec Corticas SA & POR \\
\hline
\end{tabular}

Explanations: RTD = Research institute, $I A G=$ association, $S M E$ = small\&medium sized enterprise

Table 1 


\begin{tabular}{|c|c|c|c|c|c|c|}
\hline \multirow[t]{2}{*}{ Raw material polymer } & \multicolumn{2}{|c|}{$100 \%$ system } & \multicolumn{2}{|c|}{ water based } & \multicolumn{2}{|c|}{ solvent based } \\
\hline & reactive & non-reactive & reactive & non-reactive & reactive & non-reactive \\
\hline Acrylic & psa labels, film/film & psa & & film/paper, psa labels & & psa, film/film \\
\hline casein & & & & $\begin{array}{l}\text { labelling, laminating, } \\
\text { cork }\end{array}$ & & \\
\hline cellulose & & & & paper sacks & & \\
\hline dextrin & & & & $\begin{array}{l}\text { labelling, most } \\
\text { packaging, mainly with } \\
\text { paper }\end{array}$ & & \\
\hline $\begin{array}{l}\text { EVA ethylene- } \\
\text { vinylacetate-copolymer }\end{array}$ & & 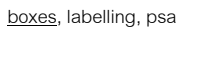 & & all type of packaging & & \\
\hline $\begin{array}{l}\text { VAE vinylacetate- } \\
\text { ethylene-copolymer }\end{array}$ & & & & $\underline{\text { boxes, paper/paper }}$ & & \\
\hline natural rubber & & & & cold seals & & psa tapes, labels, cork \\
\hline polyolefine & & $\begin{array}{l}\text { boxes, paper/film } \\
\text { hygiene art., psa, } \\
\text { labelling }\end{array}$ & & & & \\
\hline polyurethane & $\begin{array}{l}\text { film/film, clear boxes, } \\
\text { cork }\end{array}$ & film/paper & $\begin{array}{l}\text { film/film, film/paper, } \\
\text { cork }\end{array}$ & paper/paper & film/film & \\
\hline PVAc polyvinylacetate & & & & $\begin{array}{l}\text { paper/paper, wood, } \\
\text { cork packaging }\end{array}$ & & \\
\hline PVOH polyvinylalcohol & & & & $\begin{array}{l}\text { paper/paper, tissue } \\
\text { laminating }\end{array}$ & & \\
\hline starch & & $V$ & & $\begin{array}{l}\text { labelling, paper/paper, } \\
\text { corr. board }\end{array}$ & & \\
\hline synth rubber & & $\begin{array}{l}\text { paper/film, hygiene art., } \\
\text { boxes, labelling, psa }\end{array}$ & & $\begin{array}{l}\text { film/paper, film/board, } \\
\text { alu/paper, alu/board }\end{array}$ & & psa \\
\hline epoxy based & structural applications & & & & & \\
\hline $\begin{array}{l}\text { melamine } \\
\text { formaldehyde }\end{array}$ & & & wood, cork & & & \\
\hline $\begin{array}{l}\text { formalehyde } \\
\text { condensation products }\end{array}$ & & & & paper/paper & & \\
\hline PVP polyvinylpyrollidon & & labelling & & & & \\
\hline polyvinylether & & & & labelling & & \\
\hline glucose & & & & paper/paper, tissue & & \\
\hline water-glass & & & & tissue & & \\
\hline
\end{tabular}

Explanations: The test systems in the project are marked grey and the applications underlined

Table 2 